\title{
Analisis Biaya Riil Dan Kesesuaian Dengan Tarif INA-CBGs Pada Pasien Kanker Ovarium RS Di Kota Surakarta Tahun 2018
}

\section{Analysis Real Cost And Compatibility With INA-CBGs Tariff Ovarian Cancer Patient In General Hospital Surakarta 2018}

\author{
Eka Oktafiani ${ }^{1}$, Rina Herowati ${ }^{1}$, Tri Murti Andayani ${ }^{2}$ \\ ${ }^{1}$ Fakultas Farmasi, Universitas Setia Budi Surakarta \\ ${ }^{2}$ Fakultas Farmasi, Universitas Gadjah Mada \\ Email: ekaoktafiani15@gmail.com
}

(tanggal diterima: 30-04-2020, tanggal disetujui: 24-09-2020)

INTISARI

Kanker ovarium menurut Indonesian Society Gynecologic Oncology berada pada urutan kedua setelah kanker serviks. Pengobatan kanker ovarium dilakukan dengan pembedahan, radioterapi, dan kemoterapi. Tujuan penelitian untuk mengetahui kesesuaian biaya riil dengan tarif INA-CBGs dan faktor-faktor yang mempengaruhi biaya riil pada pasien kanker ovarium RS di Kota Surakarta.

Penelitian ini bersifat observasi analitik, data diambil secara retrospektif. Subyek penelitian adalah pasien kanker ovarium yang rawat inap di RS Kota Surakarta tahun 2018. Analisis yang digunakan one sample t-test dan analisis korelasi multivariat untuk mengetahui hubungan biaya riil dengan faktor-faktor yang mempengaruhi biaya riil.

Hasil penelitian menunjukkan terdapat 93 pasien, 87 pasien dengan kemoterapi dan 24 pasien dengan pembedahan. Hasil menunjukkan biaya riil lebih tinggi dari tarif INA-CBGs pada kelas kemoterapi C-4-13-I kelas 3 memiliki selisih Rp -2.685.296, pembedahan W-1-20-I kelas 1 dengan selisih Rp -3.486.814, kelas 3 selisihnya Rp -6.933.878, pembedahan W-1-20-II kelas 2 selisihnya Rp -6.492.889, kelas 3 selisihnya Rp -20.450.634, dan pembedahan W-4-10-III kelas 2 selisihnya Rp 13.714.831. Faktor yang mempengaruhi biaya riil diantaranya LOS (Length Of Stay) $(\mathrm{p}=0,000)$ pada tindakan kemoterapi. Pasien dengan siklus kemoterapi yang tidak teratur lebih banyak, namun ratarata biaya kemoterapinya hampir sama dengan pasien yang siklus kemoterapinya teratur.

Kata kunci: kanker ovarium, kemoterapi, pembedahan, tarif INA-CBGs, biaya riil

ABSTRACT
Ovarian cancer according to the Indonesian Society of Gynecologic Oncology is second only to cervical cancer. Ovarian cancer treatment is done with surgery, radiotherapy, and chemotherapy. The research objective was to determine the suitability of the real costs with the INA-CBGs rates and the factors that affect the real costs of ovarian cancer patients at the Hospital in Surakarta.

This research is an analytical observation, the data is taken retrospectively. The research subjects were ovarian cancer patients who were hospitalized at the Surakarta City Hospital in 2018. The analysis used a one-sample t-test and multivariate correlation analysis to determine the relationship between real costs and factors that affect real costs.

The results showed that there were 93 patients, 87 patients with chemotherapy, and 24 patients with surgery. The results show that real cost is higher than the INA-CBGs rate in the chemotherapy C-4-13-I class 3 has a difference of Rp-2,685,296, surgery W-1-20-I class 1 a difference of Rp-3,486,814, class 3 the difference is Rp -6,933,878, surgery W-20-II class 2 the difference is Rp $-6,492,889$, the difference is Rp -20.450 .634 in class 3, and surgery W-4-10-III class 2 the difference is $\mathrm{Rp}-13,714,831$. The factor that influences the real cost is LOS (Length Of Stay) $(\mathrm{p}=0,000)$ on chemotherapy. Patients with chemotherapy cycles were more irregular, but the average cost of chemotherapy was almost the same as patients with regular chemotherapy cycles.

Keywords: ovarian cancer, chemotherapy, surgery, INA-CBG rates, real costs 


\section{PENDAHULUAN}

Kanker ovarium menurut Indonesian Society of Gynecologic Oncology berada pada urutan kedua setelah kanker serviks. Penderita yang dating biasanya berada pada stadium II-IV (42,5\%) sehingga keberhasilan pengobatan sangat rendah [1]. Pulau Jawa merupakan pulau dengan penderita kanker terbanyak sebesar 71,9\% dan provinsi Jawa Tengah merupakan provinsi dengan jumlah penderita kanker terbanyak. Angka kejadian banyak terjadi pada usia dewasa sekitar 75,1\% [2]. Kanker ovarium berada diurutan kedua setelah kanker serviks di RSUP Sanglah pada periode Juli 2013-2014. Kanker ovarium ditemukan paling banyak pada saat stadium III dan IV [3]. Pengobatan kanker ovarium dapat dilakukan dengan pembedahan, radioterapi, dan kemoterapi. Pengobatan dilakukan dengan mempertimbangkan stadium kanker, karakteristik dan tipe tumor, usia dan kesehatan pasien [4]. Belum diketahui secara pasti berapa besaran biaya terapi pada kanker ovarium, namun menurut penelitian sebelumnya tingkat keparahan I ratarata LOS pengobatan kanker serviks dengan radioterapi menunjukkan adanya perbedaan dengan LOS INA-DRG [5]. Komponen biaya yang muncul pada terapi pembedahan terdiri dari biaya sarana, biaya BHP (Bahan Medis Habis Pakai), biaya jasa dokter, biaya jasa anastesi, biaya pemeriksaan penunjang, biaya rawat inap, dan biaya obat [6].

Penelitian sebelumnya di RSUD Dr. Moewardi Surakarta menyatakan bahwa terdapat selisih negatif antara biaya riil dengan tarif INA-CBGs pada penyakit kanker payudara. Selisih negatif yaitu biaya riil lebih besar dibandingkan tarif INA-CBGs. Hal ini disebabkan karena pada tingkat keparahan I memiliki jumlah episode perawatan terbanyak, mempunyai lebih dari 1 diagnosis sekunder, dan memiliki lebih dari 2 prosedur [7]. Berdasarkan studi literatur, maka perlu dilakukan analisis biaya riil dan kesesuaian dengan tarif INA-CBGs pada kanker ovarium karena tidak menutup kemungkinan faktor-faktor yang mempengaruhi biaya riil pada penelitian sebelumnya juga dapat mempengaruhi biaya riil pada pasien kanker ovarium sehingga dapat terjadi perbedaan antara biaya riil dengan tarif INA-CBGs.

\section{METODE PENELITIAN}

Penelitian ini dilaksanakan dengan metode observasi analitik dengan rancangan penelitian yang digunakan adalah cross sectional menurut perspektif rumah sakit. Pengambilan data secara retrospektif melalui penelusuran rekam medik pasien periode Januari - Desember 2018 dan data biaya pengobatan pasien di bidang pengelolaan dan pendapatan. Subyek penelitian adalah pasien yang memenuhi kriteria inklusi yaitu pasien yang memiliki catatan rekam medik dan data biaya pengobatan yang lengkap. Kriteria eksklusi yaitu pasien yang meninggal dan pulang paksa. Analisis data yang digunakan analisis deskriptif, analisis one sample ttest dan analisis korelasi bivariat.

\section{HASIL DAN PEMBAHASAN}

Hasil penelitian periode Januari-Desember 2018 RS di Kota Surakarta pada pasien kanker ovarium terdapat 93 pasien yang memenuhi kriteria inklusi. Pasien 
yang masuk dalam klasifikasi kemoterapi sebanyak 87 pasien dengan 299 episode perawatan dan pasien yang masuk dalam klasifikasi pembedahan berjumlah 24 pasien.

Tabel 1. Data umur pada pasien kanker ovarium RS di Kota Surakarta tahun 2018

\begin{tabular}{|c|c|c|c|c|}
\hline $\begin{array}{c}\text { Karakteristik } \\
\text { pasien }\end{array}$ & $\begin{array}{l}\text { Kelompok } \\
\text { (tahun) }\end{array}$ & Jumlah pasien & Persentase $(\%)$ & Total pasien \\
\hline \multirow{5}{*}{ Umur } & $<30$ & 5 & 5.38 & 93 \\
\hline & $31-40$ & 12 & 12.90 & \\
\hline & $41-50$ & 22 & 23.66 & \\
\hline & $51-60$ & 27 & 29.03 & \\
\hline & $>60$ & 27 & 29.03 & \\
\hline
\end{tabular}

Pengelompokkan umur berdasarkan tabel 1 menunjukkan persentase tertinggi terdapat pada kelompok umur 51-60 tahun dan > 60 tahun. Hal ini membuktikan bahwa angka kejadian kanker ovarium terjadi pada wanita yang sudah menopause dengan risiko 4,6 kali lebih besar dibandingkan wanita yang belum menopause [8]. Penelitian sebelumnya menyatakan bahwa menopause biasa terjadi pada umur $\geq 50$ tahun [9]. Persentase tertinggi kedua terdapat pada kelompok umur 41-50 tahun hal ini sejalan dengan penelitian sebelumnya bahwa kejadian kanker ovarium mengalami peningkatan dengan bertambahnya umur sekitar 41-50 tahun [10].

\section{1 Distribusi diagnosis sekunder}

Pasien kanker ovarium RS di Kota Surakarta memiliki berbagai macam diagnosis sekunder seperti yang ditampilkan pada tabel 2 .

Tabel 2. Distribusi diagnosis sekunder pasien kemoterapi kanker ovarium di RS Surakarta tahun 2018

\begin{tabular}{|l|c|c|}
\hline \multicolumn{1}{|c|}{$\begin{array}{c}\text { Dumlah episode } \\
\text { perawatan }(\mathbf{n = 5 4})\end{array}$} & $\begin{array}{c}\text { Persentase } \\
(\%)\end{array}$ \\
\hline D63.0 (Anemia in neoplastic disease) & 41 & 75,93 \\
\hline D69.6 (Thrombocytopenia) & 1 & 1,85 \\
\hline D70 (Neutropenia) & 3 & 5,56 \\
\hline D72.819 (Leukopenia) & 1 & 1,85 \\
\hline E11 (Type 2 diabetes mellitus) & 1 & 1,85 \\
\hline I10 (Essential (primary) hypertension) & 3 & 1,85 \\
\hline R72.9 (Hepatic failure) & 1 & 1,85 \\
\hline N17.9 (Acute kidney failure) & 1 & 1,85 \\
\hline R18 (Ascites) & 1 & 1,85 \\
\hline C79.5 (Secondary malignant neoplasm of bone & 1 & \\
\hline and bone marrow) & & \\
\hline
\end{tabular}

Berdasarkan tabel 2 diagnosis sekunder yang sering dialami pasien kemoterapi kanker ovarium adalah D63.0 (Anemia in neoplastic disease), diagnosis sekunder D70 (Neutropenia) dan I10 (Essential primary hypertension) berada diurutan kedua. Terjadinya anemia pada pasien kanker adalah temuan yang umum karena persentase kejadiannya antara 30-90\%. Agen kemoterapi menyebabkan anemia dengan mengganggu hematopoiesis, regimen berbasis platinum juga dapat 
menyebabkan anemia karena efek toksik pada sumsum tulang dan ginjal [10].

Tabel 3. Distribusi diagnosis sekunder pasien pembedahan kanker ovarium di RS Surakarta tahun 2018

\begin{tabular}{|c|c|c|}
\hline Diagnosis sekunder & $\begin{array}{l}\text { Jumlah pasien } \\
\qquad(n=54)\end{array}$ & $\begin{array}{l}\text { Persentase } \\
(\%)\end{array}$ \\
\hline D63.0 (Anemia in neoplastic disease) & 11 & 55 \\
\hline D69.6 (Thrombocytopenia) & 1 & 5 \\
\hline $\begin{array}{l}\text { E11.9 (Type } 2 \text { diabetes mellitus without } \\
\text { complications) }\end{array}$ & 1 & 5 \\
\hline $\begin{array}{l}\text { E88.0 (Disorders of plasma-protein metabolism, not } \\
\text { elsewhere classified) }\end{array}$ & 2 & 10 \\
\hline I10 (Essential (primary) hypertension) & 1 & 5 \\
\hline J90 (Pleural effusion, not elsewhere classified) & 1 & 5 \\
\hline N13.3 (Unspecified hydronephrosis) & 3 & 15 \\
\hline
\end{tabular}

Tabel 3 menunjukkan pasien kanker ovarium yang menjalani pembedahan lebih banyak mempunyai diagnosis sekunder D63 (Anemia in neoplastic disease). Penelitian Indriani menyatakan bahwa sebanyak 196 kasus tindakan operatif pada kanker ovarium mengalami perdarahan 1000-2000 cc [11]. Perdarahan intraoperative biasa terjadi pada tindakan histerektomi dengan persentase 1-2\%. Perdarahan intraoperatif merupakan suatu kondisi pasien kehilangan darah lebih dari 1 L sehingga memerlukan transfusi darah. Perdarahan sendiri merupakan komplikasi yang ditakuti saat pembedahan [12].

Tabel 4. Karakteristik distribusi LOS pasien kanker ovarium di RS Surakarta tahun 2018

\begin{tabular}{|c|c|c|c|c|}
\hline Tingkat keparahan & $\begin{array}{c}\text { Kelas } \\
\text { perawatan }\end{array}$ & Rata-rata & Min (hari) & Max (hari) \\
\hline \multirow[t]{3}{*}{$\begin{array}{c}\text { Kemoterapi } \\
\text { C-4-13-I } \\
\end{array}$} & Kelas 1 & 1,49 & 1 & 5 \\
\hline & Kelas 2 & 1,66 & 1 & 8 \\
\hline & Kelas 3 & 1 & 1 & 7 \\
\hline \multirow[t]{3}{*}{ C-4-13-II } & Kelas 1 & 3 & 2 & 4 \\
\hline & Kelas 2 & 4,33 & 3 & 7 \\
\hline & Kelas 3 & 3 & 2 & 8 \\
\hline C-4-13-III & Kelas 3 & 3 & 3 & 3 \\
\hline \multirow[t]{3}{*}{$\begin{array}{c}\text { Prosedur pada rahim } \& \\
\text { adneksa } \\
\text { W-1-20-I }\end{array}$} & Kelas 1 & 15 & - & - \\
\hline & Kelas 2 & 11 & - & - \\
\hline & Kelas 3 & 6,63 & 5 & 10 \\
\hline \multirow[t]{2}{*}{ W-1-20-II } & Kelas 2 & 7 & - & - \\
\hline & Kelas 3 & 11 & 6 & 16 \\
\hline $\begin{array}{c}\text { Tumor sistem reproduksi } \\
\text { wanita } \\
\text { W-4-10-I }\end{array}$ & Kelas 2 & 3 & - & - \\
\hline W-4-10-II & Kelas 3 & 4 & 1 & 7 \\
\hline W-4-10-III & Kelas 2 & 3 & - & - \\
\hline
\end{tabular}

Tabel 4 menunjukkan bahwa kode kemoterapi C-4-13-II kelas perawatan 2 mempunyai rata-rata yang paling tinggi disebabkan karena pada pasien tidak 
langsung mendapatkan kemoterapi melainkan mendapatkan penanganan anemia yaitu transfusi darah, setelah 5 hari kemudian pasien mendapatkan tindakan kemoterapi. Pada kode prosedur pada rahim \& adneksa W-1-20-I kelas perawatan 1 rata-rata tertinggi lama rawat inap adalah selama 15 hari dikarenakan pasien mendapatkan banyak prosedur yaitu 65.12 (other biopsy of ovary), 65.61 (other removal of both ovaries and tubes at same operative episode), 67.4 (amputation of cervix), 68.69 (other and unspecified radical abdominal hysterectomy), 89.52 (electrocardiogram), 99.18 (injection of anticoagulant). Lamanya rawat inap pada pembedahan dihubungkan dengan jenis operasi, selain itu pembedahan memiliki risiko komplikasi sehingga membutuhkan perawatan dengan intensitas yang tinggi [13].

\subsection{Analisis biaya berdasarkan tarif INA-CBGs}

Besarnya selisih biaya diperoleh dari total tarif INA-CBGs dikurangi dengan total biaya riil. Tabel 5 menggambarkan selisih total tarif INA-CBGs dengan total biaya riil di RS Surakarta tahun 2018.

Tabel 5. Selisih antara total biaya riil dengan total tarif INA-CBGs pasien kanker ovarium di RS Surakarta tahun 2018

\begin{tabular}{|c|c|c|c|}
\hline Tingkat keparahan & $\begin{array}{l}\text { Total tarif INA-CBGs } \\
\text { (Rp) }\end{array}$ & Total biaya rill (Rp) & Selisih (Rp) \\
\hline \multicolumn{4}{|l|}{ Kemoterapi C-4-13-I } \\
\hline Kelas 1 & 159.281.300 & 137.732 .236 & 21.549 .064 \\
\hline Kelas 2 & 221.400 .000 & 201.234 .889 & 20.165 .111 \\
\hline Kelas 3 & 461.250 .000 & 463.935 .296 & -2.685 .296 \\
\hline \multicolumn{4}{|l|}{ Kemoterapi C-4-13-II } \\
\hline Kelas 1 & 105.324 .700 & 64.194 .329 & 41.130 .371 \\
\hline Kelas 2 & 20.833 .500 & 12.961 .196 & 7.872 .304 \\
\hline Kelas 3 & 150.464 .600 & 109.453 .278 & 41.011 .322 \\
\hline \multicolumn{4}{|c|}{ Kemoterapi C-4-13-III } \\
\hline Kelas 3 & 23.501 .400 & 8.296 .060 & 15.205 .340 \\
\hline \multicolumn{4}{|c|}{ Prosedur pada rahim \& adneksa W-1-20-I } \\
\hline Kelas 1 & 16.051 .600 & 19.538.414 & -3.486 .814 \\
\hline Kelas 2 & 13.758 .500 & 10.080 .922 & 3.677 .578 \\
\hline Kelas 3 & 91.723 .200 & 98.657 .078 & -6.933 .878 \\
\hline \multicolumn{4}{|c|}{ Prosedur pada rahim $\&$ adneksa W-1-20-II } \\
\hline Kelas 2 & 17.191 .400 & 23.684 .289 & -6.492 .889 \\
\hline Kelas 3 & 42.978 .300 & 63.428 .934 & -20.450 .634 \\
\hline \multicolumn{4}{|c|}{ Tumor sistem reproduksi wanita W-4-10-III } \\
\hline Kelas 2 & 16.954 .100 & 30.668 .931 & -13.714 .831 \\
\hline
\end{tabular}

Hasil tabel 5 menunjukkan terdapat selisih negatif antara total biaya riil dengan tarif INA-CBGs. Total selisih biaya terbesar terjadi pada kode kemoterapi C4-13-I kelas perawatan 3, kode prosedur pada rahim \& adneksa W-1-20-I kelas perawatan 1 dan 3, kode pembedahan W-1-20-II kelas perawatan 2 dan 3, serta kode pembedahan W-4-10-III kelas perawatan 2. Penyebab terjadinya selisih 
negatif karena biaya riil lebih besar dibandingkan dengan tarif INA-CBGs. Penelitian Primananda membuktikan bahwa terjadi total selisih negatif terbesar pada kode C-4-13-I kelas perawatan 3 [14]. Pada kode pembedahan W-1-20-I kelas perawatan 1 dan 3, kode pembedahan W-1-20-II kelas perawatan 2 dan 3, serta kode pembedahan W-4-10-III kelas perawatan 2 mengalami selisih negatif dipengaruhi oleh besarnya biaya medik, biaya obat dan BMHP (Bahan Medis Habis Pakai) pasien. Biaya medik, biaya obat dan BMHP yang besar dikarenakan pasien mendapatkan tindakan prosedur yang berbeda tergantung dari tingkat keparahan pasien, selain itu diagnosis sekunder juga dapat mempengaruhi besarnya biaya medik, biaya obat dan BMHP.

Tabel 6. Perbandingan antara rata-rata biaya riil dengan tarif INA-CBGs pasien kanker ovarium di RS Surakarta tahun 2018

\begin{tabular}{|c|c|c|c|c|c|c|}
\hline $\begin{array}{c}\text { Tingkat } \\
\text { keparahan }\end{array}$ & $\begin{array}{c}\text { Kelas } \\
\text { perawatan }\end{array}$ & $\begin{array}{c}\text { Rata-rata } \\
\text { biaya riil } \\
\text { (Rp) }\end{array}$ & $\begin{array}{l}\text { Tarif INA- } \\
\text { CBGs (Rp) }\end{array}$ & Min (Rp) & $\operatorname{Max}(\mathrm{Rp})$ & p \\
\hline \multicolumn{7}{|l|}{ Kemoterapi } \\
\hline \multirow[t]{3}{*}{ C-4-13-I } & Kelas 1 & 3.722 .493 & 4.304 .900 & 2.447 .864 & 5.097 .503 & 0,000 \\
\hline & Kelas 2 & 3.353 .915 & 3.690 .000 & 1.954 .310 & 5.070 .581 & 0,000 \\
\hline & Kelas 3 & 3.092 .902 & 3.075 .000 & 1.722 .957 & 4.964 .329 & 0,000 \\
\hline \multirow{3}{*}{ C-4-13-II } & Kelas 1 & 4.938 .025 & 8.101 .900 & 2.833 .439 & 6.483 .156 & 0,000 \\
\hline & Kelas 2 & 4.320 .399 & 6.944 .500 & 3.761 .631 & 4.689 .159 & 0,004 \\
\hline & Kelas 3 & 4.209 .741 & 5.787 .100 & 2.343 .517 & 7.261 .692 & 0,000 \\
\hline C-4-13-III & Kelas 3 & 2.765 .353 & 7.833 .800 & 2.537 .973 & 3.169 .909 & 0,005 \\
\hline \multicolumn{7}{|c|}{ Prosedur pada rahim $\&$ adneksa } \\
\hline \multirow[t]{3}{*}{ W-1-20-I } & Kelas 1 & 19.538 .414 & 16.051 .600 & - & - & - \\
\hline & Kelas 2 & 10.080 .922 & 13.758 .500 & - & - & - \\
\hline & Kelas 3 & 12.332 .135 & 11.456 .400 & 8.488 .621 & 22.511 .721 & 0,000 \\
\hline \multirow[t]{2}{*}{ W-1-20-II } & Kelas 2 & 23.684 .289 & 17.191 .400 & - & - & - \\
\hline & Kelas 3 & 63.428 .934 & 42.978 .300 & 15.041 .036 & 27.566 .911 & 0,028 \\
\hline \multicolumn{7}{|c|}{ Tumor sistem reproduksi wanita } \\
\hline W-4-10-III & Kelas 2 & 30.668 .931 & 16.954 .100 & - & - & - \\
\hline
\end{tabular}

Keterangan: p (nilai signifikansi)

Nilai rata-rata biaya riil pada kemoterapi C-4-13-I/II/III lebih kecil dibandingkan dengan tarif INA-CBGs, kecuali pada kemoterapi C-4-13-I kelas 3 ratarata biaya riil lebih besar dibandingkan tarif INA-CBGs. Biaya minimum dan maksimum pada kemoterapi C-4-13-I/II/III memiliki nilai rentang biaya yang cukup tinggi hal ini dikarenakan besarnya biaya medik, penunjang medik, obat dan BMHP, serta akomodasi sehingga rentang biaya minimum dan maksimum pada semua tingkat keparahan kemoterapi sangat jauh berbeda. Berdasarkan analisis one sample t-test kode W-1-20 kelas perawatan 3 tingkat keparahan I dan II hasil nilai signifikansi $\mathrm{p}<0,05$ yang berarti terdapat perbedaan secara bermakna berdasarkan tarif INA-CBGs. Rata-rata biaya riil kelas perawatan 3 tingkat keparahan I dan II lebih besar dibandingkan tarif INA-CBGs hal ini disebabkan karena tingginya biaya medik serta biaya obat dan BMHP. Karena tingginya biaya medik serta biaya obat 
dan BMHP maka biaya minimun dan maksimum kelas perawatan 3 tingkat keparahan I dan II memiliki rentang biaya yang cukup tinggi. Rumah sakit perlu melakukan pengelolaan terhadap komponen biaya pengobatan dengan membuat clinical pathway yang berisi langkah-langkah penanganan pasien yang terdiri dari protokol terapi serta standar pelayanan pasien agar dapat menekan pembengkakan biaya sehingga biaya riil tidak melebihi tarif INA-CBGs.

\subsection{Faktor yang mempengaruhi biaya riil}

Analisis korelasi faktor yang mempengaruhi biaya riil merupakan analisis yang digunakan untuk mengetahui pengaruh umur dan LOS terhadap biaya riil pasien kanker ovarium di RS Surakarta. Hasil analisis korelasi dapat dilihat pada tabel 7.

Tabel 7. Hasil analisis korelasi faktor yang mempengaruhi biaya riil pasien kanker ovarium di RS Surakarta tahun 2018

\begin{tabular}{|c|c|c|c|c|c|c|}
\hline \multirow{3}{*}{ Faktor } & \multicolumn{6}{|c|}{ Biaya riil } \\
\hline & \multicolumn{2}{|c|}{$\begin{array}{c}\text { Kemoterapi } \\
\text { C-4-13 }\end{array}$} & \multicolumn{2}{|c|}{$\begin{array}{c}\text { Prosedur pada rahim \& } \\
\text { adneksa } \\
\text { W-1-20 }\end{array}$} & \multicolumn{2}{|c|}{$\begin{array}{c}\text { Tumor sistem reproduksi } \\
\text { wanita } \\
\text { W-4-10 }\end{array}$} \\
\hline & $r$ & $\mathrm{P}$ & $r$ & $\mathrm{p}$ & $r$ & $\mathrm{p}$ \\
\hline Umur & 0,030 & 0,608 & 0,054 & 0,856 & $-0,209$ & 0,562 \\
\hline LOS & 0,561 & 0,000 & 0,414 & 0,141 & $-0,065$ & 0,859 \\
\hline
\end{tabular}

Keterangan: r (nilai korelasi)

Hasil analisis korelasi pada tabel 7 menunjukkan kode kemoterapi C-4-13 LOS memiliki nilai signifikan $\mathrm{p}<0,05$ sehingga berpengaruh terhadap biaya riil sedangkan dilihat pada nilai $r=0,561$ yang berarti hubungan antara LOS dengan biaya riil bersifat sedang dan arah hubungan adalah positif karena nilai $r$ positif, berarti semakin lama LOS maka semakin meningkat biaya riil. Lama perawatan akan menambah biaya terutama biaya lama rawat inap karena biaya tersebut dihitung per hari sehingga semakin lama perawatan maka biaya yang lain pun juga akan meningkat. Satu faktor yang mempengaruhi besarnya biaya riil pasien kanker paru di Rumah Sakit Islam Sultan Agung Semarang adalah lama perawatan [15].

\subsection{Analisis keteraturan siklus}

Analisis keteraturan pola siklus kemoterapi pada pasien kanker ovarium di RS Surakarta dilakukan untuk melihat perbedaan biaya pola siklus kemoterapi dan disesuaikan berdasarkan keteraturan interval dan jumlah siklus. Dalam penelitian ini, peneliti menetapkan minimal 6 kali episode kemoterapi yang dilakukan selama tahun 2018. Berikut adalah tabel siklus kemoterapi pasien kanker ovarium di RS Surakarta tahun 2018.

Tabel 8. Pola siklus kemoterapi pada pasien kanker ovarium di RS Surakarta 2018

\begin{tabular}{|c|c|c|c|}
\hline $\begin{array}{l}\text { Jumlah pasien } \\
\qquad(n=87)\end{array}$ & Keteraturan siklus & $\begin{array}{l}\text { Total biaya rill } \\
\text { kemoterapi (Rp) }\end{array}$ & Rata-rata (Rp) \\
\hline 12 & Teratur & 248.696 .643 & 3.406 .803 \\
\hline 75 & Tidak teratur & 770.566 .207 & 3.409 .584 \\
\hline
\end{tabular}


Berdasarkan tabel 8 sebanyak 75 siklus kemoterapi dari 87 pasien kemoterapi kanker ovarium di RS Surakarta mengalami pola siklus tidak teratur yang artinya pasien menjalani kemoterapi dengan interval tanggal pulang sebelumnya dan tanggal masuk selanjutnya kurang dari 21 hari dan lebih dari 28 hari, sedangkan untuk pola siklus kemoterapi teratur dengan interval siklus 21 sampai 28 hari dialami 6 siklus kemoterapi. Ketidakteraturan siklus kemoterapi dapat dilihat bahwa pasien yang tidak teratur siklus kemoterapinya lebih banyak dibandingkan dengan pasien yang siklus kemoterapinya teratur.

Regimen terapi kemoterapi yang paling sering digunakan pada pasien 10 besar penyakit kanker adalah carboplatin dan paclitaxel kemudian diurutan kedua adalah regimen terapi cisplatin dan paclitaxel. Efek samping yang terjadi pada regimen terapi paclitaxel dan karboplatin/cisplatin yaitu alergi, leukopenia, neutropenia, muntah, dan rambut rontok [16]. Menurut Zulkarnain bahwa regimen terapi paclitaxel dan cisplatin menyebabkan penurunan hemoglobin, neutrofil dan trombosit pasca kemoterapi [17]. Hal ini akan berdampak pada keberhasilan proses pengobatan kanker ovarium. Maka dapat dinyatakan bahwa perlu adanya edukasi petugas medis kepada pasien agar menjalankan terapi kemoterapi sesuai dengan interval waktu pemberian standar kemoterapi. Penelitian Mahmuddin menjelaskan bahwa terdapat hubungan antara lama kemoterapi dengan kualitas hidup pasien, dimana arah hubungan adalah positif yakni semakin lama pasien menjalani kemoterapi maka akan semakin tinggi nilai kualitas hidup penderita kanker [18].

\section{KESIMPULAN}

Dari hasil penelitian disimpulkan bahwa terdapat perbedaan antara biaya riil terhadap tarif INA-CBGs pada pasien kanker ovarium pada kode kemoterapi C-4-13I kelas perawatan 3 dengan selisih Rp. -2.685.296, pada kode prosedur pada rahim dan adneksa W-1-20-I kelas perawatan kelas 3 dengan selisih Rp. -6.933.878, dan kode prosedur pada rahim dan adneksa W-1-20-II kelas perawatan 3 dengan selisih Rp. -20.450.634. Faktor yang mempengaruhi biaya riil pasien kanker ovarium di RS Surakarta tahun 2018 adalah LOS pada kode kemoterapi C-4-13, sedangkan pada kode yang lain umur dan LOS tidak berpengaruh. Pasien dengan siklus kemoterapi yang tidak teratur lebih banyak, namun rata-rata biaya kemoterapinya hampir sama dengan pasien yang siklus kemoterapinya teratur.

\section{UCAPAN TERIMAKASIH}

Kepada RS di Kota Surakarta yang telah memberikan izin untuk menggunakan data penderita kanker ovarium, para staf rekam medik dan staf bagian pengelolaan dan pendapatan yang telah membantu mencarikan data pasien kanker ovarium.

\section{DAFTAR PUSTAKA}

[1]. Himpunan Onkologi Ginekologi Indonesia. Pedoman Nasional Pelayanan Kedokteran Kanker Ovarium. 2018. 
[2]. Makassari D. Sebaran Kanker di Indonesia, Riset Kesehatan Dasar 2007. Indonesian Journal of Cancer. 2017;11:1-8.

[3]. Dhitayoni I \& Budiana I. Profil Pasien Kanker Ovarium Di Rumah Sakit Umum Pusat Sanglah Denpasar - Bali Periode Juli 2013 - Juni 2014. E-Jurnal Medika Udayana. 2017; 6: 1-9.

[4]. American Cancer Society. Treating Ovarian Cancer. 2018. https://www.cancer.org/cancer/ovarian-cancer/treating.html (3 Oktober 2019).

[5]. Oktaviani D, Dwiprahasto I, Andayani TM. Analisis Biaya Pengobatan Kanker Serviks Sebagai Pertimbangan dalam Penetapan Pembiayaan Kesehatan Berdasarkan INA-DRGs di RSUD Dr. Moewardi. Jurnal Manajemen dan Pelayanan Farmasi 2012;5:1-7.

[6]. Purnama V, Andayani TM, Fudholi A. Analisis Biaya Terapi Pada Kanker Payudara Dengan Terapi Hormon. Jurnal Manajemen dan Pelayanan Farmasi 2015;5:1-7.

[7]. Dewi BA. Analisis Kesesuaian Biaya Terapi Riil Dengan Tarif INA-CBG's Pasien Rawat Inap Kanker Payudara Dengan Kemoterapi Di RSUD Dr. Moewardi Surakarta Tahun 2017. 2018 [Tesis]. Surakarta: Fakultas Farmasi, Universitas Setia Budi.

[8]. Yanti DAM, \& Sulistianingsih A. Faktor determinat terjadinya kanker ovarium di Rumah Sakit Umum Daerah Abdoel Moeloek Provinsi Lampung 2015. Keperawatan 2016;7:79-87.

[9]. Rosyada MA, Pradigdo SF, Aruben R. Faktor-Faktor yang Berhubungan dengan Usia Menopause. Jurnal Kesehatan Masyarakat 2016;4:241-248.

[10]. Febriani A \& Rahmawati Y. Efek Samping Hematologi Akibat Kemoterapi dan Tatalaksananya. Jurnal Respirasi. 2019;5:22-28.

[11]. Indriani, R., Amarullah Ritonga, M., \& Suardi, D. Evaluasi Tindakan Operatif pada Kanker Serviks, Endometrium, dan Ovarium di RSUP Dr. Hasan Sadikin Bandung Tahun 2015-2016. Indonesian Journal of Obstetrics \& Gynecology Science. 2018; 1:79-86. https://doi.org/10.24198/obgynia.v1n2.49

[12]. Yu, S. P., Cohen, J. G., \& Parker, W. H. Management of hemorrhage during gynecologic surgery. Clinical Obstetrics and Gynecology. 2015;58:718-731. https://doi.org/10.1097/GRF.0000000000000147.

[13]. Rahmawati E, Al Asba Z, Aprina. Faktor-faktor yang berhubungan dengan lama perawatan pasien pasca operasi di ruang rawat inap bedah rumah sakit. Jurnal Keperawatan 2017;13:195-202.

[14]. Primananda AZ. Analisis Kesesuaian Biaya Riil Dengan Biaya INA-CBG's Pada Pasien Kemoterapi Kanker Paru-Paru Rawat Inap Peserta JKN RSUD Dr. Moewardi Surakarta Tahun 2017. 2018 [Tesis]. Surakarta: Fakultas Farmasi, Universitas Setia Budi.

[15]. Andriani M, Fudholi A, Andayani TM. Analisis biaya terapi pada penyakit kanker paru rawat inap jaminan kesehatan nasional di RSI. Sultan Agung Semarang. 2019 [abstrak]. Yogyakarta: Fakultas Farmasi, Universitas Gadjah Mada. 
[16]. Darmawan E, Melani R, Raharjo B. Gambaran hubungan regimen dosis dan efek samping kemoterapi pada pasien kanker di RSUD Prof. Dr. Margono Soekarjo Purwokerto periode bulan Januari-Februari tahun 2019. Majalah Farmaseutik. 2019; 5:113-122.

[17]. Zulkarnain I, Surarso B, Purnami N. 2017. Penurunan hemoglobin, neutrofil, dan trombosit pascakemoterapi cisplatin-paclitaxel pada penderita tumor ganas kepala dan leher. Jurnal THT. 2017;10:1-10.

[18]. Mahmuddin, Lestari DR, Rizany I. Hubungan lama menjalani kemoterapi dengan kualitas hidup penderita kanker payudara di RSUD Ulin Bamjarmasin. Dinamika Kesehatan Jurnal Kebidanan dan Keperawatan. 2019;10:254-265. 